Jumal Sosialisasi

Jurnal Hasil Pemikiran, Penelitian, dan Pengembangan

Keilmuan Sosiologi Pendidikan

Vol 8, Nomor 1, Maret 2021

\title{
REMAJA PUTUS SEKOLAH PADA KOMUNITAS PEKERJA SAWAH DI DESA LEWORENG KECAMATAN DONRI-DONRI KABUPATEN SOPPENG
}

\author{
Mauliadi Ramli \\ ${ }^{1}$ Program Studi Sosiologi, Fakultas Ilmu Sosial, Universitas Negeri Makassar \\ mauliadiramli@unm.ac.id
}

\begin{abstract}
ABSTRAK
Penelitian ini bertujuan untuk mengetahui bagaimana faktor penyebab remaja putus sekolah dan peran orang tua dalam menghadapi remaja yang putus sekolah di Desa Leworeng Kecamatan Donri-Donri kabupaten Soppeng. Penelitian ini bersifat deskriptif kualitatif yang menggambarkan masalah remaja putus sekolah Hasil penelitian menunjukkan bahwa orang tua di Desa Leworeng tidak mampu menjalankan menjalankan fungsi keluarga dengan baik sehingga anaknya putus sekolah, hal ini dikarenakan tingkat pendidikan orang tua yang rendah, pendidikan dianggap bukan perioritas utama, ibu yang bekerja mencari nafkah, banyaknya jumlah anak dalam keluarga, dan faktor ekonomi keluarga. Adapun faktor penyebab remaja putus sekolah yakni dari lingkungan keluarga antara lain kasih sayang dari orang tua sangat berpengaruh terhadap keadaan psikologis anak, pola pikir anak yang dipengaruhi oleh lingkungan keluarga, kondisi dalam lingkungan keluarga yang kurang mendukung, sikap pasrah dan tidak mau peduli orang tua terhadap kondisi dan perkembangan anak secara maksimal, dan kondisi ekonomi orang tua. Adapun faktor pendukung berhentinya anak dari bangku sekolah di Desa Leworeng Kecamatan Donri-Donri kabupaten Soppeng antara lain dari lingkungan sekolah yakni sikap guru di sekolah, aturan sekolah yang menjadi beban, teman-teman di sekolah serta prestasi anak di sekolah. Sedangkan faktor dari lingkungan tempat tinggal, kondisi lingkungan yang berpotensi negative yakni jumlah anak yang sering mabuk-mabuk,judi togel jauh lebih banyak dari pada jumlah remaja mesjid mencerminkan lingkungan pergaualan yang buruk.
\end{abstract}

Kata kunci: Remaja Putus sekolah, Pekerja Sawah.

\begin{abstract}
This study aims to determine the factors that cause teenagers to drop out of school and the role of parents in dealing with teenagers who drop out of school in Leworeng Village, Donri-Donri District, Soppeng Regency. This research is descriptive qualitative which describes the problem of dropping out of school adolescents. The results showed that parents in Leworeng Village were not able to carry out family functions properly so that their children dropped out of school, this was due to the low level of education of parents, education was considered not the main priority. who work for a living, the large number of children in the family, and family economic factors. The factors that cause adolescents to drop out of school, namely from the family environment, among others, the affection of parents is very influential on the psychological state of the child, the child's mindset is influenced by the family environment, the conditions in the family environment are less supportive, the attitude of surrender and not wanting to care about parents the condition and maximum development of the child, and the economic condition of the parents. The supporting factors for stopping children from school in Leworeng Village, Donri-Donri District, Soppeng district include the school environment, namely the attitude of teachers at school, school rules that become a burden, friends at school and children's achievements at school. While the factors of the environment where they live, the environmental conditions that have the potential to be negative, namely the number of children who often get drunk, lottery gambling is far more than the number of youth in the mosque, which reflects a bad social environment.
\end{abstract}

Keywords: Teenagers dropping out of school, rice field workers. 


\section{PENDAHULUAN}

Pertanian sebagai salah satu sektor paling besar dan berperan sangat dominan dalam membangun bangsa ini merupakan sektor yang secara absolut sampai saat ini masih tetap dan akan terus berperan penting sebagai salah satu faktor kunci keberhasilan pembangunan ekonomi nasional termasuk pembangunan ekonomi wilayah Sulawesi Selatan karena sebagian besar masyarakat Sulawesi Selatan bermata pencaharian atau menggantungkan hidupnya pada kegiatan usaha pertanian. Petani yang sebagian besar pelakunya adalah kaum pria yang juga sebagai kepala keluarga dalam membantu ekonomi keluarga adalah hal yang tidak asing lagi bagi masyarakat pedesaan khususnya di wilayah Sulawesi Selatan. Tapi tak jarang di antara meraka adalah pria yang masih usia remaja bahkan anak anak yang seharusnya remaja usia mereka sepatutnya menikmati dunia pendidikan sebagaimana di atur dalam pasal 31 ayat 1 UUD 1945 bahwa setiap warga negara berhak mendapat Pendidikan (Purnama, 2019).

Sebagaimana kita ketahui pendidikan merupakan kebutuhan dasar manusia. Setiap manusia membutuhkan pendidikan, baik pendidikan formal, non formal, maupun informal. Melalui pendidikan akan tercipta generasi penerus bangsa yang berkualitas dan tangguh yang memiliki kemampuan intelektual sehingga dapat dijadikan sumber daya manusia yang berpotensi untuk memimpin bangsa dan negara kearah kemajuan berdasarkan Pancasila dan Undang-undang Dasar 1945 (Suprayitno \& Wahyudi, 2020), (Awaru, 2020). Hal ini berarti dalam upaya pembinaan dan pengembangan potensi, minat, dan bakat generasi muda sudah pasti memerlukan pendidikan. Pengembangan generasi muda diarahkan untuk mempersiapkan kader penerus perjuangan bangsa dan pembangunan nasional dengan memberikan bekal keterampilan kepemimpinan, kesegaran jasmani dan kreasi, patriotisme, idealisme, kepribadian, dan budi pekerti yang luhur. Untuk itu perlu diciptakan iklim yang sehat sehingga memungkinkan kreativitas generasi muda berkembang secara wajar dan bertanggung jawab. Dalam rangka itu perlu usaha-usaha guna mengembangkan generasi muda untuk melihat remaja dalam proses kehidupan berbangsa dan bernegara serta pelaksanaan pembangunan nasional (Suprayitno \& Wahyudi, 2020). Hal ini berarti remaja perlu mendapat perhatian khusus dalam pendidikan dan keikutsertaannya dalam masyarakat karena mereka mempunyai kewajiban yang harus didukung hak-haknya untuk mempersiapkan diri sebagai generasi yang ada.

Pendidikan adalah hal yang sangat mendasar bagi pembangunan bangsa dan merupakan hak setiap anak Indonesia (Ali, 2009). Namun pada kenyataannya tidak semua anak dapat memperoleh pendidikan sebagaimana mestinya, hal ini disebabkan oleh beberapa seperti: faktor ekonomi (kemiskinan), faktor lingkungan pergaulan, faktor internal si anak, namun yang lebih utama adalah faktor kemiskinan, terlebih lagi anak yang orang tuanya atau salah satu orang tuanya telah meninggal dunia, sehingga anak terpaksa putus sekolah karena tidak sanggup membayar uang sekolah. Apalagi mengingat tingginya biaya untuk dapat memperoleh pendidikan.

Data dari Departemen Pendidikan Nasional menyatakan setidaknya ada 1,5 juta anak usia sekolah (13-18 tahun) terpaksa keluar dari bangku sekolah setiap tahun disebabkan karena kondisi ekonomi keluarga yang memprihatinkan. Kondisi ekonomi seperti ini menjadi penghambat bagi seseorang untuk memenuhi keinginannya dalam melanjutkan pendidikan. Sementara kondisi ekonomi seperti ini disebabkan berbagai faktor, di antaranya orang tua tidak mempunyai pekerjaan tetap, tidak mempunyai keterampilan khusus, keterbatasan kemampuan dan faktor lainnya (Dewi et al., 2014). di Desa Leworeng Kecamatan Donri-donri Kabupaten Soppeng masih terdapat anak ataupun 
remaja yang putus sekolah dan sebagian besar dari mereka terjun dalam dunia pertanian baik itu hanya sekedar membantu orang tua bahkan menjadi petani sewaaan, atas dasar inilah penulis mencoba menganalisa penyebab remaja putus sekolah pada komunitas pekerja sawah di Desa Leworeng Kab. Soppeng.

\section{METODE PENELITIAN}

Di dalam penelitian ini menggunakan metode penelitian kualitatif. Penentuan sasaran informan penelitian dilakukan dengan menggunakan teknik Purpossive Sampling dengan menentukan kriteria (Tanjung, 2021). Melihat keterbatasan peneliti maka dalam penelitian ini hanya mengambil beberapa informan dengan menarik 12 orang informan dengan kriteria yaitu remaja pekerja sawah yang putus sekolah sebanyak 7 orang dan 5 anggota keluarga yang memiliki anak putus sekolah. Teknik pengumpulan data dilakukan melalui observasi, wawancara, dan dokumentasi dengan tahap teknik analisis data kualiatatif yang bersifat deskriptif yaitu mengumpulkan data, reduksi data, menyajikan data, dan menarik kesimpulan (Nazir, 1988).

\section{HASIL PENELITIAN DAN PEMBAHASAN}

\section{Faktor Yang Menyebabkan Banyaknya Remaja Yang Putus Sekolah di Desa Leworeng} Kec Donri-Donri Kab Soppeng

Berdasarkan hasil survei lapangan di Desa Leworeng Kec Donri -Donri Kab Soppeng, adapun beberapa faktor penyebab putus sekolah dari lingkungan keluarga dengan melihat banyaknya fungsi keluarga yang tidak berjalan maksimal yakni antara lain:

a. Suasana Dalam Lingkungan Keluarga: orang tua harus mampu menjalankan peranannya dengan baik sesuai dengan status mereka masing-masing dan mampu membuat suasana dalam lingkungan keluarga mereka menjadi lebih nyaman dan aman. Namun hal ini tidak ditemui pada sebagian besar informan bahkan sebagian besar keluarga tidak menerapkan kehidupan religius terhadap anak mereka padahal agama merupakan komponen penting dalam membimbing akhlak dan watak anak.

b. Sikap Pasrah dan Tidak Mau Peduli Orang Tua: sikap acuh, pasrah dan gampang mengalah dengan keadaan membuat sebagian besar orang tua gagal mendidik anak mereka. Yang akan berpengaruh pada pola pikir dan persepsi anak tentang pentingnya sebuah pendidikan karena tidak adanya motivasi dari orang tua. Anggapan orang tua yang menilai anak yang memilki IQ (Intelligence Quotient) rendah lebih baik berhenti sekolah, menjadi penyebab putusnya pendidikan anak (Wahyuni, 2010). Hal ini tentu dipengaruhi oleh tingkat pendidikan orang tua si anak.

c. Kasih Sayang Dari Orang Tua: Kasih sayang dalam keluarga sangat penting, karena hal itu akan berpengaruh terhadap kejiwaan atau psikologis anak. Kekurangan kasih sayang dari orang tua menyebabkan anak merasakan kurangnya perhatian dari orang tua dan lebih menyukai berada di luar rumah untuk mencari sosok pengganti. Tentu hal ini menyebabkan orang tua lengah dalam pengawasan, terlebih lagi jika si anak bertemu dengan teman yang memilki latar belakang yang sama dan membuat si anak lebih nyaman berada seharian di luar rumah.

d. Pola pikir anak : Kebanyakan anak putus sekolah di Desa Leworeng mengaku lebih memilih bekerja dan berhenti sekolah karena dengan bekerja mereka dengan mudah mendapat uang dan dapat membeli kebutuhan pribadi mereka walaupun hanya sebagai petani sewaan. Orientasi masa depan yang tidak jelas mengakibatkan sebagian mereka cepat mengambil keputusan tanpa pertimbangan secara matang dan berperilaku konsumtif ini terjadi karena tingkat pendidikan orang tua yang rendah berpengaruh 
terhadap pola pikir si anak. Seperti Asse (17 Tahun) yang memilih berhenti sekolah dan bekerja sebagai petani, padahal orang tuanya masih mampu untuk menafkahinya. Kondisi Ekonomi Orang tua: kondisi ekonomi orang tua yang labil membuat anak terpaksa berhenti sekolah dan membantu orang tua mencari nafkah untuk memenuhi kebutuhan hidup.

Adapun faktor pendukung dalam kasus putus sekolah yang terjadi di Desa Leworeng antara lain dari lingkungan sekolah yakni sikap guru di sekolah, begitu juga dengan aturan sekolah, teman-teman di sekolah serta prestasi anak di sekolah turut mempengaruhi mereka untuk berhenti sekolah. Sebagian besar anak dijadikan informan terjerumus dalam lingkungan pergaulan mereka,anak yang tadinya hanya ikut-ikutan minum minuman keras untuk mencari teman justru lebih memilih meninggalkan bangku sekolah dan memilih bekerja karena dengan bekerja mereka dengan leluasa mebeli kebutuhan mereka yang cenderung kearah negative.

2. Peran Orang Tua Dalam Menghadapi Kasus Putus Sekolah di Desa leworeng Kec donri-Donri Kab Soppeng

Keluarga adalah lembaga sosial dasar dari mana semua lembaga atau pranata sosial lainnya berkembang. Keluarga merupakan kelompok sosial terkecil dalam masyarakat yang umumnya terdiri dari ayah, ibu dan anak. Menurut Herbert Spencer dalam (Poloma, 2000) keluarga sebagai suatu organisme hidup sama-sama mengalami pertumbuhan, disebabkan oleh pertambahan dalam ukurannya, maka struktur tubuh-sosial (social body) maupun organisme hidup (living body) itu mengalami pertambahan pula; dimana semakin besar suatu struktur sosial maka semakin banyak pula bagian-bagiannya, tiap bagian tubuh di dalam organisme biologis maupun organisme sosial memilki fungsi dan tujuan tertentu; mereka tumbuh menjadi organ yang berbeda dengan tugas yang berbeda pula. Pada manusia, hati memilki struktur dan fungsi yang berbeda dengan paru-paru; demikian juga dengan keluarga sebagai struktur institusianal memilki tujuan yang berbeda dengan sistem politik dan ekonomi (Jones, 2010). Baik dalam sistem organisme maupun sistem sosial, perubahan pada satu bagian akan mengakibatkan perubahan pada bagian lain dan pada akhirnya pada sistem secara keseluruhan. Demikian juga keluarga, keluarga adalah struktur yang memilki bagian yang saling berhubungan. Ayah adalah salah satu bagian dari struktur. Apabila ayah sakit, atau meninggal maka beberapa fungsi dalam keluarga akan terganggu. Bagian-bagian tersebut walau saling berkaitan merupakan struktur mikro yang dapat dipelajari secara terpisah . Berdasarkan hasil survei di lapangan maka yang terjadi pada keluarga di desa leworeng Kec Donri-donri Kab Soppeng menunjuk pada peran orang tua yang gagal dalam menghadapi anaknya hingga putus sekolah melihat hampir semua fungsi keluarga tidak dapat berjalan maksimal. Hal ini dikarenakan oleh berbagai faktor antara lain:

a. Tingkat Pendidikan Orang Tua: keluarga yang berada pada garis kemiskinan memiliki tingkat pendidikan yang rendah pula, hal ini tentu saja berpengaruh terhadap bagaimana orang tua membimbing dan menghadapi anak mereka (Oktama, 2013). Rendahnya tingkat pendidikan kepala keluarga berpengaruh terhadap rendahnya tingkat pendidikan anakditemukan bahwa tingkat pendidikan orang tua yang rendah akan mempengaruhi sikap orang tua dalam menghadapi si anak antara lain sikap tidak ingin tahu, masa bodoh, dan pasrah dengan keadaan. Hal ini yang kemudian membuat orang tua gagal dalam membimbing si anak hingga akhirnya putus sekolah.

b. Faktor nilai pentingnya pendidikan: Yaitu, rendahnya kesadaran orang tua atau masyarakat akan pentingnya pendidikan, dan tidak mempunyai orientasi masa depan yang jelas (Nurjamilah \& Ukhrotunnasihah, 2018). Perilaku sbagian masyarakat di Desa 


\section{Jumal Sosialisasi \\ Jurnal Hasil Pemikiran, Penelitian, dan Pengembangan \\ Keilmuan Sosiologi Pendidikan \\ Vol 8, Nomor 1, Maret 2021}

leworeng dalam menyekolahkan anaknya lebih banyak dipengaruhi faktor lingkungan. Mereka beranggapan bahwa dengan bekerja tanpa bersekolah pun anak-anak mereka dapat hidup layak seperti anak lainnya yang bersekolah (Wassahua, 2016).

c. Ibu Yang Bekerja di Luar Rumah: ibu yang bekerja di luar rumah tentu memilki peran ganda dan juga memilki waktu yang lebih sedikit untuk berkumpul dan mengawasi anak-anak mereka, tentu saja hal ini membuat anak cenderung menyukai berada di luar rumah lebih lama dengan lingkungan pergaulan yang tidak sehat dan menyebabkan anak malas ke sekolah dan pada akhirnya putus sekolah (Wibowo \& Saidiyah, 2018). Terlebih lagi bagi single parent yang menggantikan fungsi/peran suami sebagai ayah yang mencari nafkah untuk keluarganya. Tidak berfungsinya salah satu peran anggota dalam keluarga akan mengakibatkan terganggunya bagian yang lain (Rochaniningsih, 2014),Seperti yang terjadi pada keluarga Ibu Mase.

d. Jumlah Anak Dalam Keluarga: Hampir semua informan memilki jumlah anak yang relatif banyak, hal ini tentu saja akan mempengaruhi bagaimana orang tua menafkahi dan mendidik anak mereka. Terlihat bahwa keluarga yang memilki jumlah tanggungan yang lebih banyak menemui kesulitan dalam membimbing dan mengontrol serta memenuhi kebutuhan gizi anak mereka secara maksimal. Terutama pada keluarga kurang mampu yang sebagian besar memilki anak jauh lebih banyak dan tidak sebanding dengan penghasilan mereka.

e. Kondisi Ekonomi Keluarga: Kondisi ekonomi keluarga merupakan faktor yang menyebabkan orang tua tidak dapat menjalankan peranannya dengan baik (Rakhmawati, 2015). Keluarga yang tergolong tidak mampu atau berada pada garis kemiskinan hampir tidak dapat menjalankan semua fungsi keluarga secara maksimal. Terutama pada fungsi sosialisasi dan pendidikan yakni sebagai cerminan anak, sebagai motivator, sebagai panutan anak dan terutama fasilitator. Walaupun di kabupaten Soppeng pendidkannya gratis namun masyarakat di Desa Leworeng tetap kesulitan untuk menfasilitasi anak mereka dan membimbing anak mereka karena hampir seluruh waktu orang tua di gunakan untuk mencari nafkah.

\section{PENUTUP}

Orang tua gagal menjalankan perannya dalam artian orang tua tidak dapat menjalankan fungsi keluarga dengan baik dan maksimal sehingga anak mereka putus sekolah. Hal ini terjadi karena berbagai faktor antara lain jumlah anak dalam keluarga merupakan jumlah tanggungan yang dipikul oleh orang tua yang mempersulit orang tua untuk membimbing si anak satu persatu, orang tua yang memilki tingkat pendidikan rendah cenderung menganggap pendidikan bukan perioritas utama, gampang menyerah dengan keadaan dan tidak mau tau dengan kondisi anak secara maksimal, kondisi ekonomi keluarga juga membuat orang tua kesulitan dalam menfasilitasi anak mereka dan hampir seluruh waktu digunakan untuk mencari nafkah, dan ibu yang bekerja di luar rumah memilki peran ganda dalam keluarga membuat mereka sulit mengontrol kegiatan dan perkembangan si anak secara maksimal. Faktor penyebab mengapa anak putus sekolah dari lingkungan keluarga antara lain kasih sayang dari orang tua sangat berpengaruh terhadap keadaan psikologis anak kekurang dan kelebihan kasih sayang akan mengakibatkan mental anak menjadi rusak dan pada akhirnya putus sekolah, pola pikir anak yang dipengaruhi oleh lingkungan keluarga, kondisi dalam lingkungan keluarga yang kurang mendukung membuat anak lebih betah berada di luar rumah, sikap pasrah dan tidak mau peduli orang tua terhadap kondisi dan perkembangan anak, dan kondisi ekonomi orang tua menyebabkan anak terpaksa berhenti sekolah dan membantu orang tua mencari nafkah 
Jumal Sosiafisasi

Jurnal Hasil Pemikiran, Penelitian, dan Pengembangan Keilmuan Sosiologi Pendidiikan

Vol 8, Nomor 1, Maret 2021

walaupun pendidikan di kabupaten Soppeng gratis. Adapun faktor pendukung berhentinya anak dari bangku sekolah di desa Leworeng antara lain dari lingkungan sekolah yakni sikap guru di sekolah, begitu juga dengan aturan sekolah, teman-teman di sekolah serta prestasi anak di sekolah turut mempengaruhi mereka untuk berhenti sekolah. Sedangkan faktor dari lingkungan tempat tinggal, yakni kondisi lingkungan yang berpotensi negative sepeti jumlah anak yang sering mabuk-mabuk jauh lebuh banyak dari pada jumlah remaja mesjid.

\section{DAFTAR PUSTAKA}

Ali, M. (2009). Pendidikan untuk pembangunan nasional: menuju bangsa Indonesia yang mandiri dan berdaya saing tinggi. Grasindo.

Awaru, A. O. T. (2020). The Social Construction of Parents' Sexual Education in BugisMakassar Families. Society, 8(1), 175-190.

Dewi, N. A. K., Zukhri, A., \& Dunia, I. K. (2014). Analisis faktor-faktor penyebab anak putus sekolah usia pendidikan dasar di Kecamatan Gerokgak tahun 2012/2013. Jurnal Pendidikan Ekonomi Undiksha, 4(1).

Jones, P. (2010). Pengantar Teori-Teori Sosial: Dari Fungsionalisme hingga Postmodernisme. Yayasan Pustaka Obor Indonesia.

Nazir, M. (1988). MetodePenelitian. Jakarta: Ghalia Indonesia.

Nurjamilah, L., \& Ukhrotunnasihah, U. (2018). RENDAHNYA KESADARAN MASYARAKAT TERHADAPPENDIDIKAN DI DESA TEGALLEGA. THORIQOTUNA: Jurnal Pendidikan Islam, 1(2), 101-109.

Oktama, R. Z. (2013). Pengaruh kondisi sosial ekonomi terhadap tingkat pendidikan anak keluarga nelayan di Kelurahan Sugihwaras Kecamatan Pemalang Kabupaten Pemalang Tahun 2013. Universitas Negeri Semarang.

Poloma, M. M. (2000). Sosiologi Kontemporer, Jakarta: CV. Rajawali.

Purnama, A. (2019). PERBANDINGAN PEMIKIRAN MANSUR DAN ZUBAEDI TENTANG PENDIDIKAN ANAK USIA DINI DALAM PERSPEKTIFISLAM. IAIN Bengkulu.

Rakhmawati, I. (2015). Peran keluarga dalam pengasuhan anak. Jurnal Bimbingan Konseling Islam, 6(1), 1-18.

Rochaniningsih, N. S. (2014). Dampak pergeseran peran dan fungsi keluarga pada perilaku menyimpang remaja. Jurnal Pembangunan Pendidikan: Fondasi Dan Aplikasi, 2(1).

Suprayitno, A., \& Wahyudi, W. (2020). Pendidikan Karakter di Era Milenial. Deepublish.

Tanjung, F. (2021). Adaptasi Waria: Studi Kasus Komunitas Waria di Kabupaten Pangkep. PREDESTINASI, 13(1), 7-14.

Wahyuni, M. E. (2010). Perbedaan gangguan Psikososial pada anak dengan Intelligence Quotient rata-rata dan Intelligence Quotient di atas rata-rata di SDN Manahan Surakarta.

Wassahua, S. (2016). Analisis Faktor-Faktor Penyebab Anak Putus Sekolah Di Kampung Wara Negeri Hative Kecil Kota Ambon. Al-Iltizam: Jurnal Pendidikan Agama Islam, $1(2), 204-224$.

Wibowo, A., \& Saidiyah, S. (2018). Proses Pengasuhan Ibu Bekerja. Jurnal Psikologi Integratif, 1(2), 105-123. 